\begin{abstract}
Analiza rozkładu napięcia mięśni niemowląt urodzonych przedwcześnie na podstawie badania PodoBaby

A - opracowanie koncepcji i założeń (preparing concepts)

B - opracowanie metod (formulating methods)

$\mathrm{C}$ - przeprowadzenie badań (conducting research)

D - opracowanie wyników (processing results)

E - interpretacja i wnioski (interpretation and conclusions)

F - redakcja ostatecznej wersji (editing the final version)

\section{Analysis of muscle tone distribution in premature babies based on PodoBaby podoscope examination}

\author{
Jolanta Stępowska'1,2, A, B, E, F , Agata Pudłowska1 C, D , Anna Matlęga3, B, C, E, F, \\ Małgorzata Łukowicz ${ }^{1,2, B, F}$
}

${ }^{1}$ Akademia Wychowania Fizycznego Józefa Piłsudskiego, Wydział Rehabilitacji, Faculty of Rehabilitation, Jozef Pilsudski University of Physical Education in Warsaw

${ }^{2}$ Instytut „Pomnik - Centrum Zdrowia Dziecka”, Klinika Rehabilitacji, Children's Memorial Health Institute, Rehabilitation Clinic

${ }^{3}$ Akademia Wychowania Fizycznego Józefa Piłsudskiego, Wydział Wychowania Fizycznego, Faculty of Physical Education, Jozef Pilsudski University of Physical Education in Warsaw

\section{Streszczenie}

Wstęp: Celem pracy była ocena płaszczyzny przylegania ciała niemowląt przedwcześnie urodzonych do podłoża z uwzględnieniem rozkładu napięcia mięśni w porównaniu do wyników dzieci urodzonych o czasie.

Materiat $i$ metody: Przebadano 24 niemowlęta: 12 urodzonych przedwcześnie (przed ukończeniem 37. tygodnia ciąży) i 12 urodzonych o czasie w wieku od 3. do 6. miesiąca (wieku korygowanego). Badania przeprowadzono w Instytucie „Pomnik - Centrum Zdrowia Dziecka” w Warszawie od stycznia do czerwca 2016 roku. Przeprowadzono wywiad z rodzicami niemowląt oraz badanie na stanowisku podoskopowym PodoBaby w leżeniu tyłem i przodem. Analizowano płaszczyznę przylegania ciała niemowlęcia do podłoża: obciążenie prawej i lewej strony ciała oraz długość boków. Dokonano analizy statystycznej przy użyciu programu Statistica v.12. Zastosowano test: t-Studenta.

Wyniki: W pozycji leżenia tyłem nie wykazano istotnych różnic w obciążeniu prawej strony ciała $\mathrm{w}$ grupie niemowląt urodzonych przedwcześnie w porównaniu do dzieci urodzonych o czasie (analogicznie dla strony lewej; i w pozycji leżenia przodem). W pozycji pronacji: występuje zależność między wielkością płaszczyzny przylegania ciała niemowlęcia do podłoża a długością boków tułowia - po obciążonej stronie ciała występuje wydłużenie boku, a po odciążonej skrócenie.

Wnioski: U niemowląt urodzonych przedwcześnie zaobserwowano znaczną asymetrię w obciążeniu stron ciała, a u niemowląt urodzonych o czasie średnie wartości obciążenia są zbliżone do warunków symetrii. Badanie na PoboBaby można stosować we wczesnej diagnostyce $\mathrm{w}$ rehabilitacji pediatrycznej.
\end{abstract}

Słowa kluczowe:

email: jolantastepowska@poczta.vir.pl

Projekt finansowany ze środków MNiSW. DS 225 AWF Warszawa.

Project financed by the Ministry of Science and Higher Education.

DS 225 AWF Warsaw. 
Key words: $\quad$ PodoBaby podoscope, infantile postural asymmetry, infload

\section{Wstęp}

Wyzwaniem współczesnej rehabilitacji pediatrycznej jest wczesna diagnostyka zaburzeń neurorozwojowych. Podstawowymi elementami oceny neurologicznej niemowlęcia jest analiza jego umiejętności motorycznych. Ocenia się rozkład napięcia mięśni i umiejętność kontroli głowy. Oceny dokonuje się poprzez obserwację motoryki spontanicznej niemowlęcia przy ograniczeniu bodźców ze środowiska: wizualnych czy dźwiękowych. W praktyce klinicznej stosuje się przede wszystkim badania podmiotowe, brakuje natomiast obiektywnych, szczegółowych i powtarzalnych metod oceny rozkładu napięcia mięśni, które umożliwią jak najszybsze rozpoczęcie terapii, aby zapobiec rozwojowi niefizjologicznych wzorców ruchu. Obiektywne sposoby oceny neurologicznej dziecka mogą umożliwić odpowiedni dobór metod i środków terapeutycznych oraz monitorowanie efektów terapii.

Według koncepcji NDT Bobath (Neurodevelopmental Treatment, terapia neurorozwojowa) do prawidłowego rozwoju niemowlęcia niezbędne jest, aby dziecko miało prawidłową stabilizację centralną tułowia, która polega na zintegrowanej pracy mięśni posturalnych i napięcia mięśni oraz umożliwia utrzymanie równowagi w trakcie wykonywania aktywności ruchowych w różnych pozycjach

\section{Introduction}

Early diagnostics of neurodevelopmental disorders is a challenge of contemporary pediatric rehabilitation. The analysis of motor abilities is a basic element of neurological assessment of infants in which muscle tone distribution and head control are evaluated. Assessment is made through observations of spontaneous motor activity of infants with limited visual or audio stimuli from the environment. In clinical practice, an interview is mainly applied as a research method; however, there is a lack of objective, detailed and repeatable methods of assessing muscle tone distribution which may help to commence therapy as quickly as possible to prevent the development of non-physiological movement patterns. Objective methods of neurological evaluation of an infant may facilitate the process of a proper selection of therapeutic techniques and monitoring therapy effects.

According to the NDT/Bobath approach (Neurodevelopmental Treatment), in order to develop properly, infants need appropriate central stability of the trunk which involves integrated work of postural muscles and muscle tone and enables them to maintain balance during motor activities in different body positions [1]. Physiological movement patterns are determined by a proper muscle tone 
ciała [1]. Fizjologiczne wzorce ruchu uwarunkowane są odpowiednim rozkładem napięcia mięśni, który umożliwia pokonanie siły grawitacji i rozwój poszczególnych sekwencji ruchowych. Rozkład napięcia mięśni jest różny w zależności od wieku niemowlęcia, co umożliwia ocenę dojrzałości układu nerwowego i wykrycie ewentualnych zaburzeń rozwoju. Niemowlęta urodzone przedwcześnie mogą mieć zaburzony fizjologiczny przebieg dojrzewania organizmu i jego funkcji. Im krótszy czas trwania życia płodowego, tym noworodek jest mniej dojrzały po urodzeniu i ma mniejsze zdolności adaptacyjne do nowego środowiska.

W niniejszej pracy wykonano analizę płaszczyzny przylegania ciała niemowlęcia do podłoża u niemowląt urodzonych przedwcześnie w porównaniu do urodzonych o czasie. Poprzez zastosowanie urządzenia PodoBaby można podjąć się próby znalezienia obiektywnej i dokładnej metody oceny rozkładu napięcia posturalnego niemowląt.

Celem niniejszej pracy jest ocena płaszczyzny przylegania ciała niemowlęcia do podłoża z uwzględnieniem rozkładu napięcia mięśni.

Postawiono następujące pytania badawcze:

- Czy wielkość płaszczyzny przylegania ciała niemowlęcia do podłoża w pozycji leżenia tyłem i przodem po prawej i lewej stronie ciała różni się w grupie dzieci urodzonych przedwcześnie i o czasie?

- Czy długość boków tułowia wpływa na wielkość płaszczyzny przylegania ciała niemowlęcia do podłoża po prawej i lewej stronie ciała?

- Czy istnieje związek między wielkością płaszczyzny przylegania ciała do podłoża a długością boków

\section{Materiał i metoda}

Przebadano 24 niemowlęta $\mathrm{w}$ wieku 3-6 miesięcy: 12 niemowląt urodzonych przedwcześnie (uwzględniono wiek korygowany) i 12 o czasie. Materiał badań stanowili pacjenci Instytutu „Pomnik - Centrum Zdrowia Dziecka" w Warszawie z Oddziału Dziennego Rehabilitacji Neurologicznej Kliniki Neurologii, Epileptologii i Rehabilitacji Pediatrycznej oraz Oddziału Neonatologii, Patologii i Intensywnej Terapii.

Za kryterium włączeniu do grupy badanej ustanowiono termin porodu przed ukończonym 37. tygodniem ciąży oraz wiek korygowany 3-6 miesięcy. Postawiono następujące kryteria włączenia do distribution which makes it possible to fight gravity and develop particular motor sequences. Muscle tone distribution differs depending on an infant's age, which helps to assess the nervous system maturity and to detect potential developmental disorders. Premature infants may suffer from an impaired physiological development and function of the body. The shorter the fetal life, the less mature and less able to adapt to the new environment the infant is after birth.

In this study, support surface of premature infants was compared to support surface of full-term infants. By applying PodoBaby podoscope, an attempt was made at finding an objective and precise method of assessing infantile muscle tone distribution.

The aim of the work was to assess load surface with regard to muscle tone distribution of infants.

The following research questions were addressed:

- Does support surface on the right and left side of the body in premature infants lying in a supine and prone position differ from support surface in full-term infants?

- Does the length of trunk sides affect support surface on the right and left side of the body?

- Is there a correlation between load surface and the length of trunk sides?

\section{Material and methods}

Twenty-four infants aged 3-6 months were examined, including 12 premature infants (taking into account their adjusted age) and 12 full-term infants. They were patients of the Neurological Rehabilitation Day Ward at the Neurology, Epileptology and Pediatric Rehabilitation Clinic as well as the Neonatology, Pathology and Intensive Care Ward from the Children's Memorial Health Institute in Warsaw.

The study group inclusion criteria were as follows: birth before 37 weeks and 3-6 months of adjusted age. In turn, 3-6 months of calendar age and birth on due date (from 38 to 42 weeks) constituted the control group inclusion criteria. The exclusion criteria for both groups included central nervous system damage, genetic and metabolic diseases. An approval from the ethics committee and consent from parents of the infants were obtained.

Prior to the commencement of the study, an interview concerning pregnancy and neonatal period 
grupy kontrolnej: wiek kalendarzowy 3-6 miesięcy oraz poród o czasie (od 38. do 42. tygodnia ciąży). Kryteria wyłączenia w obu grupach to: uszkodzenie ośrodkowego układu nerwowego, choroby genetyczne i metaboliczne. Uzyskano zgodę komisji etycznej oraz rodziców na udział niemowląt $\mathrm{w}$ badaniu.

Przed rozpoczęciem badania zebrano wywiad ciążowy, okołoporodowy i stanu obecnego niemowląt oraz przeanalizowano dokumentację medyczną. Następnie wykonano nieinwazyjne badanie wielkości płaszczyzny przylegania ciała niemowlęcia do podłoża za pomocą urządzenia PodoBaby - komputerowego podoskopu do diagnozowania niemowląt i dzieci (Ryc. 1). Parametry PodoBaby as well as a current state of the infants was carried out and medical records were analysed. Then, a non -invasive measurement of support surface was performed with the use of PodoBaby - a digital podoscope for diagnosing infants and older children (fig. 1). The parameters of PodoBaby are as follows: size - 90x60x55-75 cm, examination surface - 80x50 $\mathrm{cm}$, accuracy $-1 \mathrm{~mm}, 0.1$ degree, connection USB. PodoBaby podoscope is used for examining infants and diagnosing foot disorders in children up to 5 years old (maximum weight $-25 \mathrm{~kg}$ ). Computer software connected with PodoBaby presents the results of measurements in the form of numeral parameters and printouts.

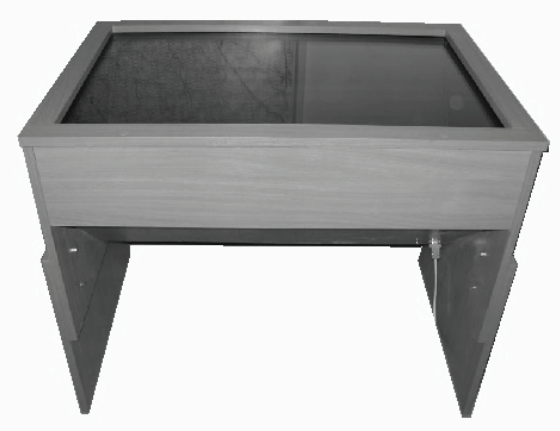

Ryc. 1. PodoBaby. Źródło: ww.cq.com.pl (16.09.2017)

Fig. 1. PodoBaby podoscope. Source: ww.cq.com.pl (16.09.2017)

są następujące: wymiary 90x60x55-75 cm, pole badania 80x50 cm, dokładność obliczeń: 1mm; 0,1 stopnia, sposób podłączenia: USB. PodoBaby stosuje się do badania niemowląt i do diagnostyki stóp dzieci do około 5 lat (do $25 \mathrm{~kg}$ ). W programie komputerowym dołączonym do PodoBaby wyniki pomiarów prezentowane są $\mathrm{w}$ postaci parametrów liczbowych oraz wydruków.

Badanie na PodoBaby umożliwia dokonanie obiektywnej oceny wielkości i układu płaszczyzny podparcia u niemowlęcia ułożonego na plecach albo brzuchu w odniesieniu do obrysu rzutu ciała.

Badanie wykonano w pozycji pronacji i supinacji. Rozebrany pacjent był układany na przezroczystej płycie PodoBaby, a następnie wykonywano z widoku od dołu fotografie komputerowe, czyli obraz był przetwarzany na sygnał cyfrowy i przesyłany do pamięci komputera za pomocą specjalnej karty. Zarejestrowany obraz był rezultatem możliwości psychomotorycznych niemowlęcia $\mathrm{w}$ momencie badania. Badanie wykonano w warunkach bezpiecznych dla niemowlęcia. Jedna z badających obsługiwała program komputerowy, a druga asekurowała dziecko leżące na stanowisku.
The measurement with the use of PodoBaby podoscope makes it possible to perform an objective assessment of support surface in an infant lying in a supine or prone position with regard to the body contour.

The examination was performed in a prone and supine position. An undressed patient was placed on a transparent PodoBaby examination surface, which allowed examiners to take digital images from the bottom side. The images were converted into a digital signal and sent to the computer memory with the use of a special card. The registered image presented psychomotor abilities of an infant at the time of an examination. The infants were examined in safe conditions. One researcher was operating computer software, while the other researcher was supporting the infant lying on PodoBaby podoscope surface.

After an infant's image was recorded in the computer software, appropriate measurement points were marked on the contour (fig. 2). The results of research were analysed with the use of a segment model and a simple ("Three areas and contour") model. 
Po zapisaniu fotografii w programie komputerowym zaznaczono odpowiednie punkty pomiarowe na sylwetce niemowlęcia (Ryc. 2). Wyniki badań opracowano przy użyciu modelu segmentowego oraz prostego (,,3 powierzchnie + obrys").
In the "Three surfaces and contour" model, the main support surfaces were marked with points oP1-P3. Three surfaces were marked in a supine position (oP1 - surface located at the highest point, i.e. on the head; oP2 - surface in the upper part of the

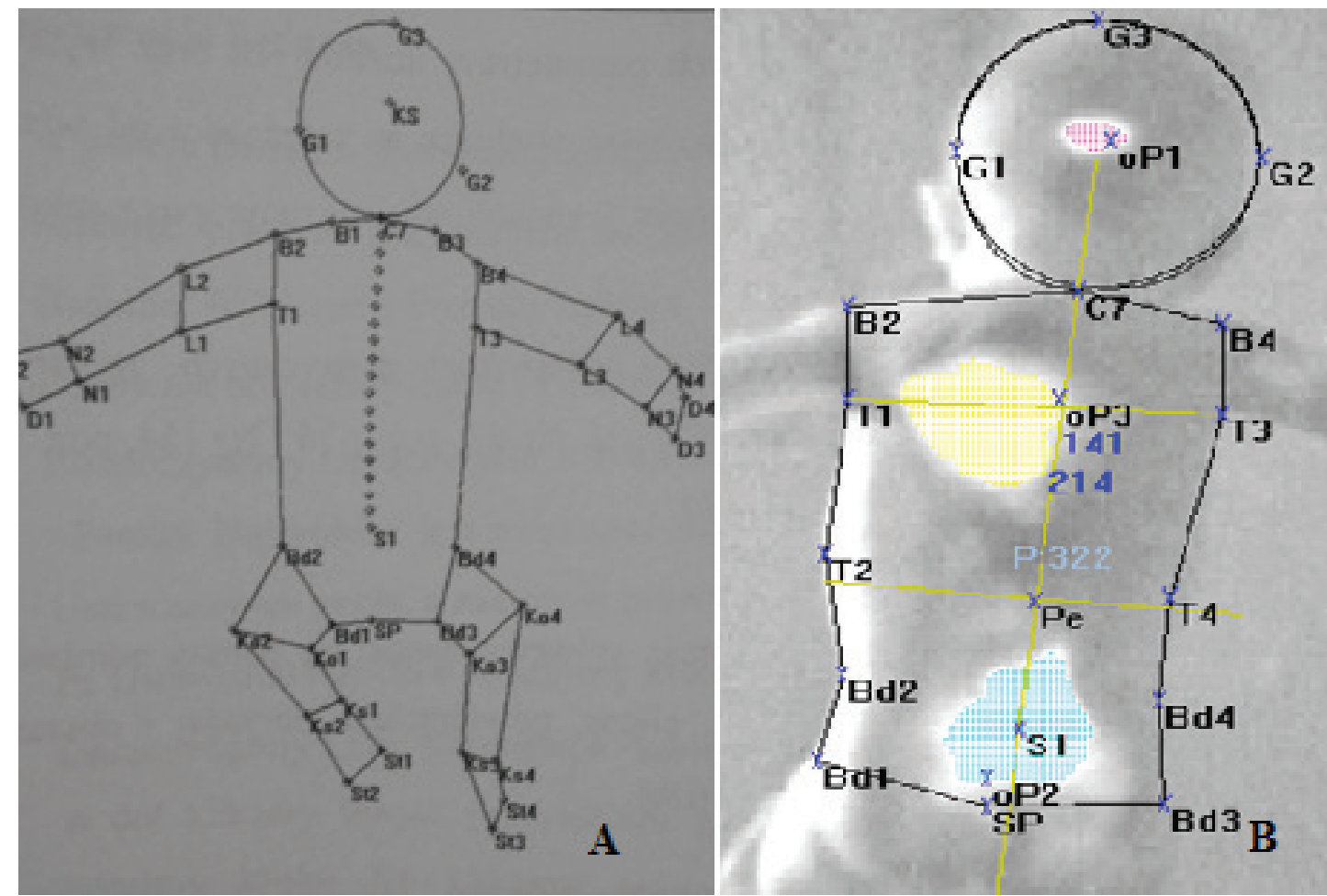

G - głowa, Ks - guzowatość potyliczna, B - bark, T - pacha, L - łokieć, N - nadgarstek, D - dłoń, Bd - biodro, Ko - kolano, $\mathbf{K s}$ - kostka, $\mathbf{S}$ - stopa

$\mathbf{G}$ - head, KS - occipital tuberosity, $\mathbf{B}$ - shoulder, $\mathbf{T}$ - armpit, $\mathbf{L}$ - elbow, $\mathbf{N}$ - wrist, $\mathbf{D}$ - hand, Bd - hip, KO - knee, KS - ankle, S - foot

Ryc. 2. Model segmentowy (2A). Model „3 powierzchnie + obrys” (2B) Źródło: www.cq.com.pl

Fig. 2. Segment model (2A); "Three areas and contour" model (2B). Source: www.cq.com.pl

W modelu ,3 powierzchnie + obrys" punktami oP1-P3 zaznaczono główne powierzchnie podparcia. W supinacji oznaczano 3 obszary (oP1 - obszar położony najwyżej, na głowie, oP2 - obszar na górnej części tułowia, oP3 - obszar na dolnej części tułowia) (Ryc. 2), a w pronacji 2 (oP2 i oP3). Komputer automatycznie obliczał ich obszary oraz proporcje dla poszczególnych części po prawej i lewej stronie ciała. Porównywano zatem pola powierzchni w stosunku do osi ciała strzałkowej (prawo-lewo) trzech wymienionych wyżej obszarów. Linię osi długiej stanowiła linia poprowadzona z punktu wyrostka kolczystego C7 do pierwszego kręgu krzyżowego S1.

Analizowano wartości następujących parametrów: powierzchni pola podparcia w poszczególnych obszarach po prawej i lewej stronie ciała oraz długość boków tułowia. trunk; oP3 - surface in the lower part of the trunk) (fig. 2), while in a prone position, two surfaces were marked (oP2 and oP3). The computer automatically calculated the surfaces and their proportions for particular parts on the right and left side of the body. Thus, areas of the aforementioned surfaces with regard to the sagittal body axis (right-left) were compared. The longitudinal body axis was marked from the spinous process $\mathrm{C} 7$ to the first sacral vertebra $\mathrm{S} 1$.

The areas of support surface on the right and left side of the body and the lengths of trunk sides were analysed.

\section{Results}

The number of study participants is presented in table 1 . 


\section{Wyniki badań}

Liczebność badanych przedstawiono w tabeli 1 .

Tab. 1. Liczebność niemowląt $w$ grupie badanej i kontrolnej

Tab. 1. The number of infants in the study and control groups

\begin{tabular}{|c|c|c|}
\hline & $\begin{array}{c}\text { Niemowlęta przedwcześnie urodzone, } \mathbf{n} / \\
\text { Premature infants, } \mathbf{n}\end{array}$ & $\begin{array}{c}\text { Niemowlęta urodzone o czasie, } \mathbf{n} / \\
\text { Full-term infants, } \mathbf{n}\end{array}$ \\
\hline Wszyscy/Total & 12 & 12 \\
\hline $\mathrm{K} / \mathrm{F}$ & $8(66,7 \%)$ & 6 \\
\hline $\mathrm{M} / \mathrm{M}$ & $4(33,3 \%)$ & 6 \\
\hline
\end{tabular}

Dokonano analizy statystycznej wyników przy użyciu programu Statistica v.12. Wykorzystano test t-Studenta. Przyjęto, że prawdopodobieństwo jest istotne statystycznie, jeśli $\mathrm{p}<0,05$.

Przeanalizowano procentowe obciążenie względem osi pionowej ciała w leżeniu tyłem (Tab.2), a także przodem (Tab. 3).
The statistical analysis of results was performed with the use of Statistica v.12 software. The Student's t-test was applied. Statistical significance was set at the level of $\mathrm{p}<0.05$.

The percentage distribution of loads with regard to the longitudinal body axis was analysed both in a supine position (tab. 2) as well as in a prone position (tab. 3).

Tab. 2. Procentowe obciążenie prawej i lewej strony ciała oraz różnica obciążeń w leżeniu tyłem w grupie niemowląt urodzonych przedwcześnie oraz o czasie

Tab. 2. The percentage distribution of loads on the right and left side of the body in a supine position and differences regarding these loads between premature and full-term infants

\begin{tabular}{|c|c|c|c|c|c|c|}
\hline & \multicolumn{3}{|c|}{ Urodzeni przedwcześnie/Premature infants } & \multicolumn{3}{c|}{ Urodzeni o czasie/Full-term infants } \\
\hline & $\begin{array}{c}\text { \% obciążenia P/ } \\
\text { \% load R }\end{array}$ & $\begin{array}{c}\text { \% obciążenia L/ } \\
\text { \% load L }\end{array}$ & $\begin{array}{c}\text { różnica obciążenia/ } \\
\text { difference in load }\end{array}$ & $\begin{array}{c}\text { \% obciążenia P/ } \\
\text { \% load R }\end{array}$ & $\begin{array}{c}\text { \% obciążenia L/ } \\
\text { \% load L }\end{array}$ & $\begin{array}{c}\text { różnica obciążenia/ } \\
\text { difference in load }\end{array}$ \\
\hline Średnia $\pm \mathrm{SD} ;$ & $60,7 \pm 20,8$ & $39,3 \pm 20,8$ & $-21,4 \pm 41,6$ & $63,3 \pm 16,3$ & $36,7 \pm 16,3$ & $-26,6 \pm 32,6$ \\
\hline Zakres & $6,8-20,2$ & $9,8-93,2$ & $-80,3-86,3$ & $37,9-93,2$ & $6,8-62,1$ & $-86,3-24,3$ \\
\hline
\end{tabular}

$\mathrm{P}$ - P strona ciała, L - L strona ciała / $\mathrm{R}$ - right side of the body, L - left side of the body

Tab. 3. Procentowe obciążenie prawej i lewej strony ciała oraz różnica obciążeń w leżeniu przodem w grupie niemowląt urodzonych przedwcześnie oraz o czasie

Tab. 3. The percentage distribution of loads on the right and left side of the body in a prone position and differences regarding these loads between premature and full-term infants

\begin{tabular}{|c|c|c|c|c|c|c|}
\hline & \multicolumn{3}{|c|}{ Urodzeni przedwcześnie/Premature infants } & \multicolumn{3}{c|}{ Urodzeni o czasie/Full-term infants } \\
\hline & $\begin{array}{c}\text { \% obciążenia P/ } \\
\text { \% load R }\end{array}$ & $\begin{array}{c}\text { \% obciążenia L/ } \\
\text { \% load L }\end{array}$ & $\begin{array}{c}\text { \% obciążenia P/ } \\
\text { \% load R }\end{array}$ & $\begin{array}{c}\text { \% obciążenia L/ } \\
\text { \% load L }\end{array}$ & $\begin{array}{c}\text { \% obciążenia P/ } \\
\text { \% load R }\end{array}$ & $\begin{array}{c}\text { \% obciążenia L/\% } \\
\text { load L }\end{array}$ \\
\hline Średnia $\pm \mathrm{SD}$ & $60,2 \pm 13,62166$ & $39,8 \pm 13,62166$ & $20,5 \pm 27,21706$ & $53 \pm 16$ & $47 \pm 16$ & $6 \pm 32$ \\
\hline Zakres & $35,1-87,3$ & $12,7-64,9$ & $-29,7-74,5$ & $22,4-71$ & $29-77,6$ & $-55,1-42$ \\
\hline
\end{tabular}

$\mathrm{P}$ - P strona ciała, $\mathrm{L}$ - L strona ciała / $\mathrm{R}$ - right side of the body, $\mathrm{L}$ - left side of the body

Wykazano, że różnice średnich między grupami pacjentów urodzonych przedwcześnie i o czasie nie jest istotna statystycznie $(\mathrm{p}=0,98)$. Warto jednak podkreślić, że analizując każde dziecko indywidualnie można zauważyć znaczne różnice obciążenia prawej i lewej strony co świadczy o zaburzeniach napięcia mięśni i asymetrycznym ułożeniu ciała.

Wykazano, że różnice średnich między grupami niemowląt urodzonych przedwcześnie i tych o czasie nie jest istotna statystycznie $(\mathrm{p}=0.47)$.
It was revealed that differences between the means for premature infants and full-term infants were not statistically significant $(\mathrm{p}=0.98)$. However, it is worth noting that while analysing the values for each infant individually, considerable differences between the loads on the right and left side of the body could be noted, which may prove the existence of muscle tone disorders and asymmetric body position. 
Na podstawie tabeli 3. zaobserwowano, że średnie wartości obciążenia po prawej i lewej stronie w pozycji leżenia przodem u dzieci urodzonych o czasie zbliżone są do wartości charakterystycznych dla symetrii tułowia (ok. $50 \%$ po jednej i po drugiej stronie ciała), a u niemowląt przedwcześnie urodzonych wartości różnią się (60,2 do 39,8\%). Wynika $\mathrm{z}$ tego, że niemowlęta przedwcześnie urodzone prezentują asymetrię ułożeniową i nieprawidłowości w wielkości płaszczyzny przylegania ciała do podłoża po prawej i lewej stronie ciała.

Wyniki długości boków i różnicę między nimi przedstawiono w tabeli 4. Długości boków w pozycji leżenia przodem opracowano w modelu segmentowym. Analizując obciążenie po prawej i lewej stronie ciała w pozycji leżenia przodem oraz długości boków zauważono, że więcej niemowląt przedwcześnie urodzonych obciąża bardziej lewą stronę ciała, a lewy bok jest u tych dzieci dłuższy. Zatem podczas przeniesienia ciężaru ciała na lewą stronę dochodzi do wydłużenia lewego boku i skrócenia prawego.
It was revealed that the differences between the means for premature and full-term infants were not statistically significant $(p=0.47)$. On the basis of data included in table 3 it was noted that mean values of loads on the right and left body side of full-term infants lying in a prone position were close to the values typical of trunk symmetry (approximately $50 \%$ on each side of the body), while in the case of premature infants, the values differed $(60.2 \%$ to $39.8 \%)$. It leads to the conclusion that premature infants manifest infantile postural asymmetry and improper values of support surface on the right and left side of the body.

The results of the measurements of the lengths of trunk sides and differences between them are presented in table 4 . The lengths of sides in a prone position were analysed in a segment model. While analysing the load on the right and left side of the body in a prone position, an increased load on the left side of the body and a longer left side of the trunk were noted more often in premature infants. Thus, when the load is transferred to the left side, this side gets longer, while the right side gets shorter.

Tab. 4. Długość boków oraz ich różnica w grupie dzieci urodzonych przedwcześnie i o czasie w pozycji leżenia przodem Tab. 4. The lengths of trunk sides and differences between them in the groups of premature and full-term infants in a prone position

\begin{tabular}{|c|c|c|c|c|c|c|}
\hline & \multicolumn{2}{|c|}{ Urodzeni przedwcześnie/Premature infants } & \multicolumn{3}{c|}{ Urodzeni o czasie/Full-term infants } \\
\hline & $\begin{array}{c}\text { Dlugość boku P/ } \\
\text { Length of side - R }\end{array}$ & $\begin{array}{c}\text { Dlugość boku L/ } \\
\text { Length of side - L }\end{array}$ & $\begin{array}{c}\text { Różnica długości } \\
\text { boków/ Difference } \\
\text { in side lengths }\end{array}$ & $\begin{array}{c}\text { Dlugość boku P/ } \\
\text { Length of side - R }\end{array}$ & $\begin{array}{c}\text { Dlugość boku L/ } \\
\text { Length of side - L }\end{array}$ & $\begin{array}{c}\text { Różnica dlugości } \\
\text { boków/ Difference } \\
\text { in side lengths }\end{array}$ \\
\hline $\begin{array}{c}\text { Średnia } \pm \text { SD/ } \\
\text { Mean } \pm \text { SD }\end{array}$ & $187,9 \pm 15,5$ & $180,3 \pm 15,6$ & $7,7 \pm 14,6$ & $185 \pm 22,9$ & $176,3 \pm 22,8$ & $8,8 \pm 24,6$ \\
\hline Zakres/ Range & $161-216$ & $155-207$ & $-18-26$ & $141-225$ & $143-212$ & $-49-41$ \\
\hline
\end{tabular}

$\mathrm{P}$ - prawy, L - lewy / R - right, L - left

\section{Dyskusja}

W praktyce klinicznej fizjoterapeutów pracujących z niemowlętami i dziećmi stosuje się powszechnie badania podmiotowe, brakuje natomiast obiektywnych, szczegółowych i powtarzalnych metod oceny napięcia mięśni pacjenta. Dotychczas opublikowano wiele prac na temat diagnostyki niemowląt, jednak niewiele $\mathrm{z}$ niech dotyczy oceny dzieci przy zastosowaniu PodoBaby, co może wynikać z małej dostępności sprzętu.

Pyzio i wsp. badali różnicę na PodoBaby niemowlęta zdrowe i z zaburzeniami rozwoju. Wykazali oni, że różnice w obciążeniu prawej i lewej strony ciała zdrowych niemowląt nie przekraczały $18 \%$, natomiast $\mathrm{u}$ niemowląt $\mathrm{z}$ zaburzeniami

\section{Discussion}

An interview technique is often applied in the clinical practice of physiotherapists working with infants and children. However, there is a lack of objective, detailed and repeatable methods of assessing muscle tone distribution. To date, numerous studies on infant diagnostics have been published but not many of them concerned the issue of assessing infants with the use of PodoBaby podoscope, which may result from a limited availability of the device.

Pyzio et al. used PodoBaby to examine differences between healthy infants and infants with developmental disorders. They revealed that differences regarding the loads on the right and left side of the 
rozwojowymi różnice te wynosiły do $66 \%$ [2]. Z kolei Czupryna i wsp. podjęli się badań nad płaszczyzną podparcia $u$ niemowląt $z$ zaburzeniami ośrodkowego układu nerwowego. Zbadano kilkanaście niemowląt w wieku 2-3 miesięcy oraz 8 zdrowych niemowląt $z$ grupy kontrolnej. Uzyskano wyniki, iż niezależnie $\mathrm{u}$ niemowląt $\mathrm{z}$ zaburzeniami funkcjonowania układu nerwowego częściej obserwowano asymetrię tułowia w pozycji supinacji i większe obciążenie dolnych partii ciała, zwłaszcza w pozycji pronacji. Autorzy podkreślili jednak, że badanie na PodoBaby należy zakwalifikować do nowych sposobów oceny niemowląt, w związku z czym trudno porównać wyniki badań własnych do prac innych autorów [3].

Ograniczeniami dotychczasowych badań na PodoBaby są małe grupy badanych. W 2013 opublikowano jednak wyniki badań na 120 niemowlętach w wieku 3-6 miesięcy, spośród których 60 miało zaburzenia ośrodkowego układu nerwowego zdiagnozowane za pomocą metody Vojty. Stwierdzono, że rozpoznanie asymetrii tułowia w badaniu PodoBaby potwierdziło wynik wcześniejszego rozpoznania klinicznego [4].

Pyzio i wsp. dokonali oceny metody pomiarowej badania na PodoBaby. Analizowano przydatność sprzętu do oceny symetrii albo asymetrii, płaszczyzny przylegania ciała niemowlęcia do podłoża oraz przemieszczania płaszczyzny podporu wraz ze środkiem ciężkości. Badania na PodoBaby uznano za obiektywny sposób oceny pacjenta w rehabilitacji pediatrycznej [2].

W badaniach Yuge i wsp. wykazano, że jakość motoryki spontanicznej niemowląt, stała się jednym z najbardziej wiarygodnych i uzasadnionych predykatorów zaburzeń neurologicznych, szczególnie tych ciężkich. Autorzy doszli do wniosku, że ocena jakości sprawności motorycznej w wieku 3 do 5 miesięcy znacznie poprawia zdolność do identyfikacji ryzyka nieprawidłowego rozwoju [5].

W literaturze można odnaleźć również prace nad wykorzystaniem stanowiska podoskopowego PodoBaby do oceny innych pozycji. Celem pracy Adamskiej i wsp. była ocena pozycji siadu prostego niemowląt w 9. miesiącu życia na PodoBaby. Uznano, że PodoBaby może stanowić cenne uzupełnienie diagnostyki neurorozwojowej [6].

$\mathrm{W}$ podobnych badaniach przy zastosowaniu urządzenia Sensor Mass System Szopa i wsp. doszli do wniosku, że ocena rozkładu sił nacisku ciała na podłoże pozwala w sposób pośredni na ocenę body in healthy infants did not exceed $18 \%$, while in the case of infants with developmental disorders, these differences reached 66\% [2]. In turn, Czupryna et al. studied support surface in infants with disorders of the central nervous system. A dozen or so infants aged 2-3 months and 8 healthy infants from the control group were examined. It was revealed that infants with disorders of the central nervous system more often manifested trunk asymmetry in a supine position and greater loads in lower parts of the body, particularly in a prone position. However, the authors pointed out that PodoBaby examination should be treated as a new method of examining infants and therefore, it is difficult to compare the results with the findings of other authors [3].

Small study groups constitute a limitation of the studies that have been conducted with the use of PodoBaby podoscope to date. However, in 2013 the results of research conducted on 120 infants aged 3-6 months were published, where 60 study participants suffered from disorders of the central nervous system diagnosed with the use of Vojta method. It was concluded that the diagnosis of trunk asymmetry in PodoBaby examination confirmed the previous clinical diagnosis [4].

Pyzio et al. assessed PodoBaby podoscope measurement method. They analysed the usefulness of the device for assessing symmetry or asymmetry, support surface and transfer of support surface with the center of gravity. Podoscope examination was found to be an objective way of assessing a patient in pediatric rehabilitation [2].

In their research, Yuge et al. revealed that the quality of spontaneous motor activity of infants became one of the most reliable and justified predictors of neurological disorders, particularly the severe ones. The authors concluded that assessment of motor abilities in infants aged 3-5 months considerably improved the potential to identify the risk of developmental disorders [5].

In the literature, studies on the use of PodoBaby podoscope for assessing other positions can also be found. The aim of the work by Adamska et al. was to assess the position of pike sit in babies aged 9 months with the use of PodoBaby podoscope. It was revealed that PodoBaby podoscope may constitute a valuable completion of neurodevelopmental diagnostics [6].

In a similar study with the use of Sensor Mass System, Szopa et al. concluded that assessing the distribution of forces on force platform indirectly 
rozkładu napięcia mięśni w różnych formach aktywności i stanowi cenne uzupełnienie oceny jakości wzorców motorycznych. Autorzy podkreślają, że nowoczesne badania ułatwią diagnostykę, podjęcie właściwych decyzji oraz pozwolą na uzyskanie lepszych efektów terapeutycznych [7].

W badaniach własnych przyjęto podobną metodykę badania do opisanej przez Pyzio i wsp. [2,4]. Badania mają charakter badań pilotażowych i są częścią większego projektu.

\section{Wnioski}

- Nie wykazano istotnych różnic w obciążeniu prawej strony ciała $\mathrm{w}$ leżeniu tyłem $\mathrm{w}$ grupie niemowląt urodzonych przedwcześnie i o czasie (analogicznie dla strony lewej; i w pozycji leżenia przodem).

- W pozycji supinacji u niemowląt urodzonych przedwcześnie zaobserwowano znaczną asymetrię w obciążeniu stron ciała, a u niemowląt urodzonych o czasie średnie wartości obciążenia są zbliżone do warunków symetrii. Najwięcej informacji można uzyskać z analizy profilu każdego pacjenta.

- Istnieje związek między wielkością płaszczyzny przylegania ciała do podłoża, a długością boków w pozycji leżenia przodem. Po obciążonej stronie ciała obserwuje się wydłużenie boku, a po odciążonej skrócenie. allowed for evaluating muscle tone distribution in different forms of activity and constituted a valuable completion of the assessment of motor patterns quality. The authors pointed out that modern examinations would facilitate diagnosing and taking appropriate decisions as well as obtaining better therapeutic results [7].

In the present study, we adopted research methodology similar to that described by Pyzio et al. $[2,4]$. This is a pilot study which is part of a bigger research project.

\section{Conclusions}

- No significant differences between premature and full-term infants were revealed in the right side loading in a supine position (analogous lack of differences was noted for the left side and a prone position).

- In a supine position, considerable asymmetry of the loads of trunk sides was noted in premature infants, while in the case of full-term infants, the mean values of loads were close to symmetry. The majority of information may be obtained from the analysis of an individual profile of each patient.

- There exists a correlation between support surface and the length of trunk sides in a prone position. The loaded side is lengthened while the unloaded side is shortened.

\section{Piśmiennictwo}

1. Matyja M, Domagalska M. Podstawy usprawniania neurorozwojowego według Berty i Karela Bobathów. Katowice: AWF Katowice; 2009.

2. Pyzio M, Wójtowicz D, Skrzek A. Ocena asymetrii niemowląt - zestawienie badania klinicznego z badaniem podoskopowym przy użyciu stanowiska do diagnozy niemowląt PodoBaby. Pol J Physiother 2010;2(4): 156-64.

3. Czupryna K, Serkies G, Nowotny J. Płaszczyzna podparcia u niemowląt z zaburzeniami ruchowymi pochodzenia ośrodkowego. Pol J Physiother 2011;2(4): 107-33.

4. Pyzio-Kowalik M, Wójtowicz D, Skrzek A. Assessing postural asymmetry with a podoskope in infants with Central Coordination-Disturbance. Res Dev Disabil 2013;34(5):1832-42.

5. Yuge M, Marschik P, Nakajima Y, Kanda T, Hirota H, Yoshida N, Einspieler Ch. Movements and posture of infants aged 3 to 5 months. To what extent is their optimality related to perinatal events and to the neurological outcome. Early Hum Dev 2011;87(3): 231

6. Adamska A, Wójtowicz D, Ostrowska B. Ocena pozycji siedzącej u niemowląt w wieku 9 miesięcy przy użyciu stanowiska podoskopowego „Podobaby”. Inżynieria Biomedyczna 2013;19(1):49-54.

7. Szopa A, Domagalska M, Nowotny J. Rozkład sił nacisku mas ciała na podłoże u dzieci z zaburzeniami ruchowymi pochodzenia ośrodkowego jako wyraz zaburzeń rozwoju napięcia posturalnego. Pol J Physiother 2007;3(4): 250-5.

8. cq.com.pl [Internet]. Wójtowicz D, Pyzio M, Skrzek A. AWF Wrocław. Jak oceniać nowe metody pomiarowe na przykładzie PodoBaby. [cited 2017 Sep 16] Available from: http://www.cq.com.pl/publikacje/prezentacja\%20PodoBaby\%204.pdf. 